\title{
Reviews
}

\section{Proglucagon-derived peptides: nomenclature, biosynthetic relationships and physiological roles}

\author{
J.M.Conlon \\ Clinical Research Group for Gastrointestinal Endocrinology of the Max-Planck-Gesellschaft, University of Göttingen, FRG
}

The decade of the 1980s has seen enormous advances in the field of molecular endocrinology brought about in large measure by application of the methods of recombinant DNA technology. The increase in our knowledge and understanding of the glucagon-related peptides provides an excellent illustration of this point. Cloning and sequence analysis of cDNAs and DNA fragments from genomic libraries has led to the elucidation of the primary structure of the biosynthetic precursor of glucagon (pre-proglucagon) from a variety of species including man [1-6]. With this information, it has been possible to interpret the complex structural relationships between the multiple forms of the glucagon-like peptides in tissues and in the circulation. Probably the most exciting development in the field is the realisation that the pre-proglucagon gene in mammals encodes, in addition to glucagon, two additional peptides with structural similarity to glucagon, termed glucagon-like peptide-1 (GLP-1) and glucagon-like peptide-2 (GLP-2). This review attempts to summarise recent advances with a view to clarifying previous ambiguities regarding the nomenclature and biosynthetic relationships between the peptides and speculates as to the physiological role of the peptides.

\section{Nomenclature of proglucagon-derived peptides}

A previous attempt [7] to develop a workable nomenclature for the classification of glucagon-related peptides was based upon a system that characterised a peptide by its approximate molecular weight, generally determined by gel permeation chromatography, and by its reactivity towards antisera to glucagon of defined regional specificity. Glucagon, for example, was described as IRG ${ }^{3500}$. This nomenclature is subject to severe limitations as the specificities of available antisera are seldom totally clear and apparent molecular weights may be wildly inaccurate. The primary structures of the biosynthetic precursors of most of neurohormonal peptides are now known from the nucleotide sequences of cDNAs or gene fragments. It becomes possible, therefore, to use an unambiguous nomenclature that is based either on the amino acid sequence of the prohormone or, when the site of cleavage of the signal peptide is not known, on the sequence of the pre-prohormone. Even when experimental evidence is lacking, the site of signal peptide cleavage may be predicted with a high degree of probability [8] so that a nomenclature based upon the prohormone structure is generally possible and preferred.

Human pre-proglucagon is a polypeptide of 179 amino acid residues that is proteolytically cleaved by a signal peptidase at the site of the $\mathrm{Gln}^{20}-\mathrm{Arg}^{21}$ bond [1]. Amino acid residues in the signal peptide region are assigned negative numbers and the first $(\mathrm{N}$ terminal) residue in the proglucagon sequence is designated +1 . Consequently, the amino acids in the region of the site of cleavage of the signal peptide are designated: $\mathrm{Ser}^{-3}-\mathrm{Trp}^{-2}-\mathrm{GIn}^{-1}-\mathrm{Arg}^{1}-\mathrm{Ser}^{2}-\mathrm{Leu}^{3}$. All proglucagon-derived fragments are described by the residue number in proglucagon of their $\mathrm{N}$ - and $\mathrm{C}$-terminal amino acids. The systematic and trivial names of the major proglucagon-derived peptides present in tissues are compared in Figure 1 and their locations within the proglucagon molecule are shown schematically. Although the systematic nomenclature is precise, it is somewhat unwieldy for repetitive use so that a strong case may be made for the use of a trivial name, providing that the systematic name is referred to first. Thus, proglucagon (1-69) becomes glicentin or enteroglucagon and the name insulinotropin has been proposed for proglucagon (78-108) [9].

\section{Biosynthetic relationships between proglucagon-derived peptides}

The human genome probably contains only a single copy of the pre-proglucagon gene that comprises five introns and six exons $[1,10]$. However, discrepancies between the nucleotide sequences of the two reported structures of the cloned pre-proglucagon gene suggest the possibility of different alleles. Structural analysis 


\begin{tabular}{|c|c|c|}
\hline $\begin{array}{l}\text { Proglucagon } \\
\text { Residues }\end{array}$ & $\begin{array}{l}\text { Trivial } \\
\text { Name }\end{array}$ & Structural Representation \\
\hline$(1-159)$ & Proglucagon & 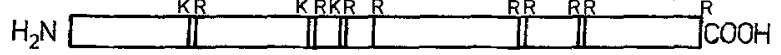 \\
\hline$(1-69)$ & $\begin{array}{l}\text { Glicentin } \\
\text { (enteroglucagon) }\end{array}$ & $\square \mathbb{I}$ \\
\hline$(1-30)$ & GRPP & $\square \square$ \\
\hline$(33-69)$ & Oxyntomodulin & $\square$ \\
\hline$(33-61)$ & Glucagon & $\square$ \\
\hline$(72-108)$ & GLP -1 & $\square$ \\
\hline$(78-108)$ & $\begin{array}{l}\text { GLP-1(7-37) } \\
\text { (insulinotropin) }\end{array}$ & $\square$ \\
\hline$(126-158)$ & GLP-2 & $\square$ \\
\hline
\end{tabular}

Fig. 1. A schematic representation of human proglucagon and the principal products of post-translational processing of proglucagon. GRPP: glicentinrelated pancreatic peptide; GLP: glucagon-like peptide, $\mathrm{K}$ : lysine, $\mathrm{R}$ : arginine. The structure of proglucagon shown is predicted from the nucleotide sequence of the gene according to [1]. The structure predicted from the nucleotide sequence in [10] contains an additional C-terminal lysine residue has shown that pre-proglucagon mRNAs in the pancreas, ileum and colon are identical [11, 12] and an identical transcriptional start site is used in the three tissues [12]. It has been concluded, therefore, that the diversity of the molecular forms of the proglucagonderived peptides in the pancreas and gut arise from different pathways of post-translational processing of the primary transcript [11]. As shown in Figure 1, human proglucagon contains several pairs of dibasic amino acid residues (Lys-Arg and Arg-Arg) which can serve as potential recognition sites for a processing enzyme [13]. In the A-cell of the pancreas, the prohormone is processed to proglucagon (1-30), which is also referred to as glicentin-related pancreatic peptide (GRPP) [14], glucagon, the hexapeptide proglucagon (64-69) [15] but the remaining C-terminal fragment proglucagon (72-158) is not processed further [16]. In the L-cell of the gut, different dibasic residue cleavage sites are used so that proglucagon is processed to proglucagon (1-69) (glicentin) [17], proglucagon (33-69), which has been termed oxyntomodulin [18], GLP-1 (proglucagon (72-108)), an intervening peptide sequence (proglucagon (111-123)) and GLP-2 (proglucagon (126-158) [11, 19]. GLP-1 is a substrate for a second proteolytic enzyme in the gut whose specificity involves cleavage at the site of single arginine residues [20]. Consequently, the predominant molecular form of GLP in the intestine of the pig [21], rat [11] and humans [22] is the truncated peptide, GLP-1 $(7-37)$. The predicted amino acid sequences of GLP-1 (7-37) and proglucagon (111-123) terminate in a glycine residue, so that there is a strong probability that the peptides contain an $\alpha$-amidated $C$-terminal residue. Experimental confirmation of this hypothesis is required. Similarly, the predicted GLP-2 sequence terminates in an arginine residue, so that, by analogy with other systems [23], it is probable that this residue is removed by the action of an endogenous carboxypeptidase B-like enzyme, e.g. carboxypeptidase H. Chromatographic evidence has been provided to show that the glucagonlike peptide formerly described as IRG ${ }^{9000}$ probably represents proglucagon (1-61) [24]. This component is found in low concentration in the pancreas, gut and plasma of healthy subjects but is elevated in the plasma of uraemic patients.

The factors regulating the tissue-specific post-translational processing of proglucagon are not understood. In rat islets, an unusual 0-glycosidic glycosylation of the prohormone takes place early in the biosynthetic process [25]. It has been shown that purified porcine glicentin is a substrate for cyclic-AMP-dependent protein kinase [26]. Thus, it is tempting to speculate that such post-translational modifications to individual amino acids may be tissue-specific and alter the susceptibility of processing sites towards the cleavage enzyme(s).

\section{Physiological roles of the proglucagon-derived peptides}

The biological significance of peptides derived from the $\mathrm{N}$-terminal region of proglucagon remains unclear. Proglucagon (1-69) (glicentin) [27], glicentin-related pancreatic polypeptide [28], oxyntomodulin [29] and the C-terminal octapeptide of oxyntomodulin [29] will inhibit, with varying degrees of potency and effectiveness, pentagastrin-stimulated gastric acid secretion in the rat. Oxyntomodulin (proglucagon (33-69)) is only one-tenth as potent as glucagon in stimulating adenylate cyclase in rat liver plasma membranes and onefifth as potent in potentiating insulin-release from the perfused rat pancreas; but the peptide is 20 -fold more potent than glucagon in inhibiting gastric acid secretion [30]. Nevertheless, a clear demonstration that the enterogastrone effect of proglucagon-derived peptides is physiologically relevant in man is needed. The asser- 
tion that proglucagon (1-69) (enteroglucagon) is a trophic factor for the intestinal mucosa is based upon indirect evidence, such as the demonstration that plasma enteroglucagon levels correlate well with crypt cell production rate in several animal models of mucosal hypertrophy [31]. It has been shown, however, that continuous in vivo immunoneutralisation of enteroglucagon using a monoclonal antibody directed against the $\mathrm{N}$-terminal to the central region of glucagon did not modify the adaptive response of the ileal remnant in rats with proximal small bowel resection [32]. The lack of availability of pure proglucagon (1-69) prevents the carrying out of definitive in vitro experiments.

Although structural similarity between the GLPs and glucagon is only moderate, the amino acid sequences of the GLPs themselves have been very strongly conserved during evolution [33]. This would suggest that the peptides are biologically important rather than merely "spacer" material in the precursor. The first attempts to determine the biological activity of GLP were performed using GLP-1 (1-37) or GLP-1 (1-36) amide. GLP-1 (1-36) amide showed only weak stimulatory activity and GLP-2 was without effect upon insulin release from isolated rat islets [33]. Similarly, GLP (1-37) was without effect on insulin release from the perfused rat pancreas in concentrations as high as $500 \mathrm{nmol} / 1$ [9]. Unprocessed GLP-1 does not increase hepatic glucose production in the rat [34] and the peptide given in high doses to ob/ob mice produced only a very small increase in plasma insulin concentrations and no change in plasma glucose [35]. In contrast, unprocessed GLP-1 binds to specific receptors in rat brain [36] and both GLP-1 and GLP-2 are potent stimulators of adenylate cyclase in rat hypothalamus and pituitary [37]. The distribution of GLP-1like immunoreactivity in the brain is similar to that of glucagon-like immunoreactivity [36] and it has been suggested that these proglucagon-derived peptides may be important as modulators of neurotransmission.

An incretin is defined as a substance produced by the gut that is released into the circulation in response to nutrients and stimulates insulin release at physiologically relevant concentrations [38]. The evidence that the truncated form of GLP-1 (GLP-1 (7-36) amide and/or GLP-1 (7-37)) is a physiologically important incretin is strong. Studies in man have demonstrated that concentrations of GLP-1 (7-36) amide-like immunoreactivity rise after oral glucose and a test breakfast [22]. Infusion of the peptide at a rate that results in an increase in concentration that mimics the post-prandial rise results in significant rises in insulin concentrations and falls in plasma glucose [22]. Studies in vitro have shown that GLP-1 (7-37) at concentrations as low as $50 \mathrm{pmol} / 1$ will increase insulin release from isolated perfused rat pancreas [9]. Studies with cells derived from a transplantable rat insulinoma (RINm5F cells) have identified high affinity binding sites for GLP-1 (7-36) amide [39] and chemical crosslinking experiments have identified a binding protein for the peptide in the plasma membrane of mol.wt.63,000 (R.Göke and J.M.Conlon, unpublished data). Binding of GLP-1 (7-36) amide to the cells resulted in an increase in the concentration of $\mathrm{cy}-$ clic AMP $[39,40]$ and stimulated insulin gene expression [40]. GLP-1 (1-36) amide bound to the cells with an affinity that was approximately 200 -fold less than that of the truncated peptide. Exogenous glucagon did not significantly influence the release of GLP-1-like immunoreactivity from isolated perfused rat pancreas [41] but further studies are necessary to determine whether proglucagon-derived peptides regulate their own secretion. Specific binding sites for GLP-1 (7-36) amide on dispersed enterocytes were not detected, which suggests, but does not prove that the peptide is not a growth factor for intestinal mucosa [39]. Clearly, further studies are warranted to examine the roles of the GLPs in the pathophysiology of diabetes and gastrointestinal and metabolic diseases. Preliminary work [22] has implicated hypersecretion of the truncated form of GLP-1 in the hyperinsulinaemia and reactive hypoglycaemia of postgastrectomy dumping syndrome.

The author of a previous review of the subject in the journal [7] considered it prudent to include a question mark in the title "The glucagon-like polypeptides - order out of chaos?" Perhaps, the question mark may now be safely omitted.

\section{References}

1. Bell GI, Sanchez-Pescador R, Laybourn PJ, Najarian RC (1983) Exon duplication and divergence in the human preproglucagon gene. Nature 304: 368-371

2. Lund PK, Goodman RH, Dee PC, Habener JF (1982) Pancreatic preproglucagon cDNA contains two glucagon-related coding sequences arranged in tandem. Proc Natl Acad Sci USA 79: 3345-3349

3. Bell GI, Santerre RF, Mullenbach GT (1983) Hamster preproglucagon contains the sequence of glucagon and two related peptides. Nature 302: 716-718

4. Lopez LC, Frazier ML, Su C, Kumar A, Saunders GF (1983) Mammalian pancreatic preproglucagon contains three glucagonrelated peptides. Proc Natl Acad Sci USA 80: 5485-5489

5. Heinrich G, Gros P, Habener JF (1984) Glucagon gene sequence: four of six exons encode separate functional domains of rat pre-proglucagon. J Biol Chem 259: 14082-14087

6. Seino S, Welsh M, Bell GI, Chan SJ, Steiner DF (1986) Mutations in the guinea pig preproglucagon gene are restricted to a speficic portion of the prohormone sequence. FEBS Lett 203: 25-30

7. Conlon JM (1980) The glucagon-like polypeptides - order out of chaos? Diabetologia 18: 85-88

8. Von Heijne G (1986) A new method for predicting signal sequence clearage sites. Nucleic Acids Res 14: 4683-4690

9. Mojsov S, Weir GC, Habener JF (1987) Insulinotropin: glucagon-like peptide $1(7-37)$ co-encoded in the glucagon gene is a potent stimulator of insulin release in the perfused rat pancreas. J Clin Invest 79: 616-619

10. White JW, Saunders GF (1986) Structure of the human glucagon gene. Nucleic Acids Res 14: 4719-4730 
11. Mojsov S, Heinrich $\mathrm{G}$, Wilson IB, Ravazzola M, Orci L, Habener J (1986) Preproglucagon gene expression in pancreas and intestine diversifies at the level of post-translational processing. J Biol Chem 261: 11880-11889

12. Novak U, Wilks A, Buell G, McEwen S (1987) Identical mRNA for preproglucagon in pancreas and gut. Eur $J$ Biochem 164: 553-558

13. Docherty K, Steiner DF (1982) Post-translational proteolysis in polypeptide hormone biosynthesis. Ann Rev Physiol 44: 625-638

14. Thim L, Moody AJ (1982) Purification and chemical characterization of a glicentin-related pancreatic peptide (proglucagon fragment) from porcine pancreas. Biochim Biophys Acta 703: 134-141

15. Yanaihara C, Matsumoto T, Hong Y-M, Yanaihara N (1985) Isolation and chemical characterization of glicentin C-terminal hexapeptide in porcine pancreas. FEBS Lett 189: 50-56

16. Patzelt C, Schiltz E (1984) Conversion of proglucagon in pancreatic alpha cells: the major endproducts are glucagon and a single peptide, the major proglucagon fragment, that contains two glucagon-like sequences. Proc Natl Acad Sci USA 81: 5007-5011

17. Thim L, Moody AJ (1981) The primary structure of porcine glicentin (proglucagon). Regul Pept 2: 139-150

18. Bataille D, Coudray AM, Carlquist M, Rosselin G, Mutt V (1982) Isolation of glucagon-37 (bioactive enteroglucagon/oxyntomodulin) from porcine jejuno-ileum. FEBS Lett 146: 73-78

19. Orskov C, Hoist JJ, Knuhtsen S, Baldissera FGA, Poulsen SS, Vagn Nielsen O (1986) Glucagon-like peptides GLP-1 and GLP2 , predicted products of the glucagon gene, are secreted separately from pig small intestine but not pancreas. Endocrinology 119: $1467-1475$

20. Schwartz TW (1986) The processing of peptide precursors: 'proline-directed arginyl cleavage' and other monobasic processing mechanisms. FEBS Lett 200: 1-10

21. Holst JJ, Orskov C, Vagn Nielson O, Schwartz TW (1987) Truncated glucagon-like peptide 1 , an insulin-releasing hormone from the distal gut. FEBS Lett 211: 169-174

22. Kreymann B, Williams G, Ghatei MA, Bloom SR (1987) Glucagon-like peptide-1 7-36: a physiological incretin in man. Lancet II: $1300-1304$

23. McGregor GP, Kage R, Conlon JM (1988) Measurement and partial characterization of the C-terminal flanking peptides from bovine preprotachykinins in extracts of brain and gut. Mol Brain Res 3: 201-214

24. Baldissera FGA, Holst JJ (1986) Glicentin (1-61) probably represents a major fraction of glucagon-related peptides in plasma of anaesthetized uremic pigs. Diabetologia 29: 462-467

25. Patzelt C, Weber B (1986) Early 0-glycosidic glycosylation of proglucagon in pancreatic islets: an unusual type of prohormonal modification. EMBO Journal 5: 2103-2108

26. Conlon JM, Thim L, Moody AJ, Söling HD (1984) Cyclic-AMPdependent phosphorylation of glicentin. Biosci Rep 4: 489-496

27. Kirkegaard P, Moody AJ, Holst JJ, Loud FB, Skov-Olsen P, Christiansen J (1982) Glicentin inhibits gastric acid secretion in the rat. Nature 297: 156-157
28. Moody AJ, Thim L, Jorgensen KD (1983) US patent No $4,405,608$

29. Jarrouse C, Andousset-Puech M-P, Dubrasquet M, Niel H, Martinez J, Bataille D (1985) Oxyntomodulin (glucagon-37) and its C-terminal octapeptide inhibit gastric acid secretion. FEBS Lett 188: 81-84

30. Kervan A, Blache P, Bataille D (1987) Distribution of oxyntomodulin and glucagon in the gastrointestinal tract and plasma of the rat. Endocrinology 121: 704-713

31. Sagor GR, Ghatei MA, Al-Mukhtar MYT, Wright NA, Bloom SR (1983) Evidence for a humoral mechanism after small bowel resection. Exclusion of gastrin but not enteroglucagon. Gastroenterology 84: 902-906

32. Gregor M, Menge H, Stössel R, Riecken EO (1987) Effect of monoclonal antibodies to enteroglucagon on ileal adaption after proximal small bowel resection. Gut 28, S1: 9-14

33. Schmidt WE, Siegel EG, Creutzfeldt W (1985) Glucagon-like peptide-1 but not glucagon-like peptide 2 stimulates insulin release from isolated rat pancreatic islets. Diabetologia 28: 704-707

34. Ghiglione M, Blasquez E, Uttenthal LO, Diego JG, Alvarez E, George SK, Bloom SR (1985) Glucagon-like-peptide-1 does not have a role in hepatic carbohydrate metabolism. Diabetologia 28: 920-921

35. Bailey CJ, Flatt PR (1987) Glucagon-like peptide 1 and the enteroinsular axis in obese, hyperglycaemic (ob/ob) mice. Life Sci 40: $521-526$

36. Shimizu I, Hirota M, Ohboshi C, Shima K (1987) Identification and localization of glucagon-like peptide- 1 and its receptor in rat brain. Endocrinology 121: 1076-1082

37. Hoosein NM, Gurd RS (1984) Human glucagon-like peptides 1 and 2 activate rat brain adenylate cyclase. FEBS Lett 178: 83-86

38. Creutzfeldt W, Ebert R (1985) New developments in the incretin concept. Diabetologia 28: 565-573

39. Göke R, Conlon JM (1988) Receptors for glucagon-like peptide$1(7-36)$ amide on rat insulinoma-derived cells. J Endocrinol 116: $367-362$

40. Drucker DJ, Philippe J, Mojsov S, Chick WL, Habener JF (1987) Glucagon-like peptide 1 stimulates insulin gene expression and increases cyclic AMP levels in a rat islet cell line. Proc Natl Acad Sci USA 84: $3434-3438$

41. Shima K, Ohboshi C, Sato M, Hirota M (1988) Effect of glucagon on secretion of glucagon-like peptide 1. Horm Metab Res 20: $123-124$

Received: 18 May 1988

and in revised form: 6 June 1988

Dr. J.M.Conlon

Klinische Arbeitsgruppe der MPG

Gosslerstraße 10D

D-3400 Göttingen

FRG 